\title{
Article
}

\section{In Vivo and In Vitro Evaluation of Preventive Activity of Inflammation and Free Radical Scavenging Potential of Plant Extracts from Oldenlandia corymbosa L.}

\author{
Mahci Al Bashera ${ }^{1,2}$, Ashik Mosaddik ${ }^{1,3}$, Gaber El-Saber Batiha ${ }^{4}$, Mohammed Alqarni ${ }^{5} \oplus$, Md. Ashraful Islam ${ }^{1}$, \\ George D. Zouganelis ${ }^{6,7, *(\mathbb{D}}$, Athanasios Alexiou ${ }^{7,8}$ and Ronok Zahan ${ }^{1, *}$ \\ 1 Department of Pharmacy, University of Rajshahi, Rajshahi 6205, Bangladesh; \\ bashera_2018@bcsir.gov.bd (M.A.B.); mamosaddik@ru.ac.bd (A.M.); maislam@vu.edu.bd (M.A.I.) \\ 2 BCSIR Laboratory, Bangladesh Council of Scientific and Industrial Research, Rajshahi 6206, Bangladesh \\ Pro VC, Varendra University, Rajshahi 6204, Bangladesh \\ 4 Department of Pharmacology and Therapeutics, Faculty of Veterinary Medicine, Damanhour University, \\ Damanhour 22511, Egypt; dr_gaber_batiha@vetmed.dmu.edu.eg \\ 5 Department of Pharmaceutical Chemistry, College of Pharmacy, Taif University, P.O. Box 11099, \\ Taif 21944, Saudi Arabia; m.aalqarni@tu.edu.sa \\ 6 School of Human Sciences, College of Life and Natural Sciences, University of Derby, Derby DE22 1GB, UK \\ 7 Novel Global Community Educational Foundation, Hebersham, NSW 2770, Australia; alexiou@ngcef.net \\ 8 AFNP Med, Haidingergasse 29, 1030 Vienna, Austria \\ * Correspondence: g.zouganelis@derby.ac.uk (G.D.Z.); rzahan.pharm@ru.ac.bd (R.Z.)
}

\section{check for} updates

Citation: Al Bashera, M.; Mosaddik, A.; El-Saber Batiha, G.; Alqarni, M.; Islam, M.A.; Zouganelis, G.D.; Alexiou, A.; Zahan, R. In Vivo and In Vitro Evaluation of Preventive Activity of Inflammation and Free Radical Scavenging Potential of Plant Extracts from Oldenlandia corymbosa L. Appl. Sci. 2021, 11, 9073. https://doi.org/ 10.3390/app11199073

Academic Editor: Marco G. Alves

Received: 2 August 2021

Accepted: 20 September 2021

Published: 29 September 2021

Publisher's Note: MDPI stays neutral with regard to jurisdictional claims in published maps and institutional affiliations.

Copyright: (c) 2021 by the authors. Licensee MDPI, Basel, Switzerland. This article is an open access article distributed under the terms and conditions of the Creative Commons Attribution (CC BY) license (https:/ / creativecommons.org/licenses/by/ $4.0 /)$.
Abstract: Aims: The present study evaluates the anti-inflammatory and antioxidant activity of the crude dichloromethane (CDCME), ethyl acetate (CEAE), and methanol (CMeE) extracts from the plant Oldenlandia corymbosa L. Background: Oldenlandia species have been popular among the people of the Indian subcontinent to treat several types of internal and external inflammation for a long time. Plant decoctions have been used to battle inflammation in cases of tonsilitis, pneumonia and cholecystitis, among others. Objective: The present work designed to demonstrate the properties of the previously mentioned plant extracts to prevent inflammation both in vivo and in vitro. This work is the first investigation of such extracts from this species and their relationship with anti-inflammatory activity. Method: The anti-inflammatory properties of the Oldenlandia corymbosa L. extracts were evaluated in vitro with the Red Blood Cell (RBC) membrane stabilization method and the protein denaturation method and in vivo with the carrageenan-induced paw oedema method. Furthermore, the free radical scavenging activity of the extracts was carried out with the 1,1-diphenyl-2- picrylhydrazyl (DPPH) radical oxidation, total antioxidant capacity and iron reduction assay. Result: Both in vivo and in vitro studies showed that CDCME had the most predominant effects with the value of $80.5 \%$ for RBC membrane stabilization, $60 \%$ for inhibition of protein denaturation at the concentration of $1000 \mu \mathrm{g} / \mathrm{mL}$ and $63.28 \%$ (after $3 \mathrm{~h}, * p<0.05)$ for inhibition of paw oedema $(300 \mathrm{mg} / \mathrm{kg} \mathrm{bwt})$ compared to carrageenan-induced mice. The free radical scavenging activity was studied by DPPH, total antioxidant and reducing activity assay. CDCME showed scavenging activity in all the methods and an $\mathrm{IC}_{50}$ value of $473.86 \mu \mathrm{g} / \mathrm{mL}$ for DPPH method. Conclusions: The findings of the study remarked that CDCME of the plant has strong anti-inflammatory and antioxidant effects that validate the traditional use of the plant to get remedy from pain. Other: The plants Oldenlandia corymbosa L. were provided by the Bangladesh Council of Scientific and Industrial Research Laboratory campus, Rajshahi, Bangladesh. Experiments on animals were conducted by ethical permission of Institute of Biological Sciences, University of Rajshahi, Bangladesh (license no: 225/320-IAMEBBC/IBSc).

Keywords: anti-inflammatory; antioxidant; DPPH; phenol; flavonoid; hemolysis 


\section{Introduction}

When any stimuli, e.g., microorganisms, injured cells or inflictors, that are not compatible with cells, are exposed to the body, a biological response occurs known as inflammation. Inflammation is characterized by classic signs like calor, dolor, rubor, tumor, and function loss. A spontaneous response is triggered by the release of cell derived mediators including vasoactive amines, cytokines, nitric oxide, prostaglandins, thromboxane A2 (TXA2), prostacyclin, leukotrienes and a platelet-activating factor (PAF) known as inflammatory mediator [1]. They are derived from inflammatory cells such as leukocytes, platelets, and vascular endothelial cells. However, it is regarded as a biological response of the intrinsic immune system, in comparison to adaptive immunity specified for each pyrogen. Acute inflammation is developed by transudation of plasma and body fluid and leukocytes' immigration in the peripheral vascular tissue and the injured site. Leukocytes accumulate following a series of the process involving migration, attachment, migration, phagocytosis and finally the extracellular release of leukocyte products [2]. Standard anti-inflammatory drugs, e.g., corticoids and NSAIDS, are used to alleviate inflammation by inhibiting the phospholipase A2 (PLA2) and cyclooxygenase (COX), respectively [3]. Prostacyclin and prostaglandin E2 are two mediators responsible for inflammatory symptoms and protection of gastric mucosa, and alleviate inflammation by inhibiting these two mediators, resulting in vomiting, nausea, gastric bleeding, and peptic ulcers [4]. Resistance to corticoids can be developed by long term use of corticoids [5]. Reactive oxygen species (ROS) and nitrogen oxygen species (NOS) contribute to promote oxidative stress that is linked with pathophysiological process of inflammation [6]. Inflammation can be attenuated by neutralizing the reactive species [7]. In almost all ancient civilizations, medicinal plants are considered a promising source to provide metabolites with logical structures that can interact with body mechanism to treat pathological complications and regenerate the body system. Phytosterol, a member of the triterpene family, can exert anti-inflammatory and antioxidant activity along with its cholesterol lowering property as it is structurally similar to cholesterol [8]. The experiment on plants based on traditional use in inflammatory reactions of cells should be considered a promising and practical research strategy in the quest for new anti-inflammatory drugs [9].

Oldenlandia species are considered as a natural source of important therapeutic value. Traditionally, plant decoctions of Oldenlandia corymbosa L. are used among various societies to treat internal and external inflammation and infection, e.g., tonsillitis, bronchitis, pneumonia, mumps, acute appendicitis, cholecystitis, pelvic infection, urinary tract infection, rheumatic fever and gout. In African cultures, the plant is used to treat hydrops and swelling, as well as used as a painkiller, while roots are used as a depressant. Some preclinical studies have revealed the plant may be regarded as a potential source of antibacterial properties [10], antimalarial [11], analgesic activity [12] and anticancer activity. This plant's ethanolic extract possesses considerable anti-nociceptive activity mediated by central and peripheral mechanisms [13]. Ethanolic and methylene chloride extracts of the plant that show potential anticancer property against YMB-1 cell line and a lead compound asperluside were considered responsible for this property [14]. Anticancer properties with combination therapy have also been demonstrated [15]. The presence of flavonols such as Quercetin, 3'-Methoxy quercetin and 3', $3^{\prime}$-Dimethoxy quercetin, phenolic acids like p-hydroxybenzoic, p-coumaric, vanillic, syringic acid, melilotic acid, ferulic and caffeic acids; anthocyanidins like cyanidin and elargonidin, as well as irridoids and alkaloids, were revealed by the analysis of methanolic extracts of Oldenlandia corymbosa L. [16]. It has been proven as a promising natural source, as it abounds with antioxidants such as ascorbic acid and polyphenolic compounds [17]. Taking into consideration these investigations, the present work was designed to demonstrate the property of the plant extracts to prevent inflammation by paw oedema method in vivo along with in vitro membrane stability and protein denaturation test. This is the first time that the anti-inflammatory activity of the particular plant extracts is investigated with the use of these methods. 


\section{Materials and Methods}

\subsection{Plant Materials}

The plants Oldendandia corymbosa L. (rubiaceae) were collected from the Bangladesh Council of Scientific and Industrial Research Laboratory campus, Rajshahi, Bangladesh $(\mathrm{N}=24.3663366, \mathrm{E}=88.6499208)$ in August 2019. The plant was verified by Dr. A.H.M. Mahbubur Rahman, Professor, Department of Botany, the University of Rajshahi, Bangladesh. The accession number is Bot-529, Date: 5 August 2019 and conserved in the Central Herbarium, Department of Botany, the University of Rajshahi, Bangladesh.

\subsection{Preparation of Plant Extract}

The aerial part of the plants was thoroughly washed with water and dehydrated in oven, at a range of temperatures of about $42-44{ }^{\circ} \mathrm{C}$ for $38 \mathrm{~h}$. The sampling materials were converted into pulverized form with a mechanical grinder, passed through sieve of mesh size 40 , and preserved in vacuum condition. At first, plant materials ( $0.25 \mathrm{~kg}$ powder) were immersed with petroleum ether $(500 \mathrm{~mL})$ and shaken vigorously in an electric shaker. The total mixture was then filtered through initially a cotton mesh, followed by Whattman No.1 filter-paper. The whole solvent with plant extract was concentrated to dryness in vacuo at $40^{\circ} \mathrm{C}$ to provide the petroleum ether extract. Thus, the extraction by petroleum ether was carried out for three times, and $0.0015 \mathrm{~kg}$ petroleum ether extract was obtained. The residue $(0.21 \mathrm{~kg})$ was soaked with about $350 \mathrm{~mL}$ dichloromethane with shaking and the solvent was evaporated to obtain dichloromethane extract. Dichloromethane extract $(0.0265 \mathrm{~kg})$, was obtained after repetition of the extraction process with dichloromethane for three times and being lyophilized. Then, the residue of the plant materials $(0.15 \mathrm{~kg})$ was immersing with ethyl acetate and the same process in case of the two solvents mentioned above was followed to obtain crude ethyl acetate extract $(0.026 \mathrm{~kg})$. Finally, the plant residue $(0.09 \mathrm{~kg})$ was immersed with methanol $(350 \mathrm{~mL})$ and the solvent was evaporated to collect the crude methanol extract. After completing three cycles of extraction with methanol, $0.032 \mathrm{~kg}$ of methanolic extract was obtained.

\subsection{Chemicals}

The required chemicals methanol, petroleum ether, dichloromethane, ethyl acetate, 2,2-diphenyl-1-picrylhydrazyl (DPPH), and phosphate buffer were purchased from Sigma Chemical, (Burlington, MA, USA). The standard like catechin, gallic acid, ascorbic acid and carrageenan were also obtained from Wako PURE CHEMICAL LTD. (Osaka, Japan).

\subsection{Animal}

Both sexes of Swiss albino mice (7-8 weeks old, $25 \pm 5 \mathrm{~g}$ bwt) were obtained from the International Centre for Diarrhea Disease Research, Bangladesh (Icd dr,B). Animals were kept inside the polypropylene cages containing hygienic bedcover things. Each cage contained 6 mice with restricted environment $\left(12: 12 \mathrm{~h}\right.$ light-dark with temperature $25^{\circ} \mathrm{C}$ and humidity average $60 \%$ ) together with the highest cleanliness. They were provided food and water for the benefit of their health. The animals were allowed to be accustomed to the space for 7 days before the experimental session. The animals were deprived of food overnight before the experiment. Experiments on animals were conducted by ethical permission and according to the instructions of the Institute of Biological Sciences, University of Rajshahi, Bangladesh (license no: 225/320-IAMEBBC/IBSc).

\subsection{Total Phenolic Content}

The total content of phenolic compounds of Oldenlandia corymbosa L. extracts was determined with the spectrophotometric method that includes Folin-Ciocalteu reagent as reactant and gallic acid as standard [18]. Folin-Ciocalteu was diluted 10 times with water. A mixture of $2.5 \mathrm{~mL}$ of diluted Folin-Ciocalteu and $2.5 \mathrm{~mL}$ of $7 \%$ sodium carbonate were added to the $0.5 \mathrm{~mL}$ of plant extract or standard solution with varying concentration $(800,400$ and $200 \mu \mathrm{g} / \mathrm{mL}$ ). These mixtures were then kept at room temperature for $20 \mathrm{~min}$. 
Spectrophotometric analysis of the samples or standard solution was carried out at a wavelength of $760 \mathrm{~nm}$. The total amount of phenolic compounds of the targeted extracts was represented as $\mathrm{mg} / \mathrm{g}$ of gallic acid equivalents (GAE) in milligram per gram (mg GAE/g) of plant extract.

\subsection{Total Flavonoid Content}

The amount of flavonoid content in Oldenlandia corymbosa L. extracts was estimated with a colorimetric method [19]. Catechin was referred to as standard and the flavonoid content of the extracts was articulated as $\mathrm{mg}$ of catechin equivalent/gm of dried extract. Plant extract or standard solution of various concentrations $(800,400$ and $200 \mu \mathrm{g} / \mathrm{mL})$ at the volume of $0.5 \mathrm{~mL}$ were taken in separate test tubes followed by addition of $2.5 \mathrm{~mL}$ of water and $0.15 \mathrm{~mL}$ of $5 \% \mathrm{NaNO}_{2}$ solution into each sample of particular density. The mixture was left to react for $5 \mathrm{~min}$. At this stage, $0.3 \mathrm{~mL}$ of $10 \%$ aluminum chloride solution and was left to be react for $5 \mathrm{~min}$. Addition of $1 \mathrm{~mL} \mathrm{NaOH}$ was followed by dilution of the mixture with $0.55 \mathrm{~mL}$ of DI water. After thorough mixing, the reaction mixtures were analyzed spectrophotometrically at a wavelength of $510 \mathrm{~nm}$ after calibration with an appropriate blank solution. The flavonoid content was expressed as $\mathrm{mg} / \mathrm{g}$ of catechine equivalents in milligrams per gram (mg CAE/g) of respective extract.

\subsection{Anti-Oxidant Activity Study}

\subsubsection{DPPH Scavenging Activity Test}

The free radical scavenging activity of extract, based on the scavenging activity of the stable 1,1-diphenyl-2-picrylhydrazyl (DPPH) free radical, was determined by the method described by Braca et al. [20]. Plant extract $(0.5 \mathrm{~mL}) /$ standard (Catechin) of varying concentrations $(800 \mu \mathrm{g} / \mathrm{mL}, 400 \mu \mathrm{g} / \mathrm{mL}$ and $200 \mu \mathrm{g} / \mathrm{mL})$ was added to $3.5 \mathrm{~mL}$ of a $0.002 \%$ $\mathrm{MeOH}$ solution of DPPH. Absorbance at $517 \mathrm{~nm}$ was determined after $30 \mathrm{~min}$, and the percentage inhibition activity was calculated from $[(\mathrm{A} 0-\mathrm{A} 1) / \mathrm{A} 0] \times 100$, where $\mathrm{A} 0$ is the absorbance of the control, and A1 is the absorbance of the extract/standard. $\mathrm{IC}_{50}$ value was calculated from the equation of the line obtained by plotting a graph of concentration $(\mu \mathrm{g} / \mathrm{mL})$ versus $\%$ inhibition.

\subsubsection{Total Antioxidant Activity Test}

The total antioxidant activity was evaluated by the phosphomolybdenum method according to the procedure of Prieto et al. [21]. The assay is based on the reduction of Mo (VI) - Mo (V) by the extract and subsequent formation of a green phosphate/Mo (V) complex at acidic $\mathrm{pH}$. Extract $(0.5 \mathrm{~mL}) /$ standard (Catechin) was combined with $3 \mathrm{~mL}$ of reagent solution ( $0.6 \mathrm{M}$ sulfuric acid, $28 \mathrm{mM}$ sodium phosphate and $4 \mathrm{mM}$ ammonium molybdate). The tubes containing the reaction solution were incubated at $95{ }^{\circ} \mathrm{C}$ for $10 \mathrm{~min}$. Then, the absorbance of the solution was measured at $695 \mathrm{~nm}$ using a spectrophotometer (Shimadzu, Kyoto, Japan, UV-150-02) against blank after cooling to room temperature. Methanol $(0.5 \mathrm{~mL})$ is used as the blank experiment.

\subsubsection{Reducing Activity Test}

The antioxidant activity of respective plant extracts was evaluated by reducing the power of responsible bioactive compounds using modified $\mathrm{Fe}^{3+}$ to $\mathrm{Fe}^{2+}$ reduction assay [22]. An aliquot of $1.0 \mathrm{~mL} \mathrm{O}$. corymbosa L. extracts/standard (Catechin) at various concentrations $(800,400,200 \mu \mathrm{g} / \mathrm{mL})$ was mixed with $2.5 \mathrm{~mL}$ of phosphate buffer $(0.2 \mathrm{M}, \mathrm{pH} 6.6)$ and $2.5 \mathrm{~mL}$ of $1 \%$ potassium ferricyanide. The mixture was incubated at $50{ }^{\circ} \mathrm{C}$ for $20 \mathrm{~min}$. The resulting solution was cooled rapidly and mixed with $2.5 \mathrm{~mL}$ of $10 \%$ trichloroacetic acid. The mixture was then centrifuged at $3000 \mathrm{rpm}$ for $10 \mathrm{~min}$. Finally, $2.5 \mathrm{~mL}$ supernatant was diluted by $2.5 \mathrm{~mL}$ of distilled water and $0.5 \mathrm{~mL}$ of $0.1 \%$ iron (III) chloride was added. Absorbance of the resultant mixture was measured at $700 \mathrm{~nm}$ at the interval of $10 \mathrm{~min}$. The higher the absorbance value indicates the stronger the reducing power. 


\subsection{In Vitro Membrane Stability Assay}

\subsubsection{Preparation of Blood Sample for Membrane Stability Assay}

A goat blood sample was collected from an animal in sound health, which has not undergone any treatment by drugs for the previous 2 weeks before the experiment [19]. Na-oxalate was used in the blood as an anticoagulant. Additionally, $4{ }^{\circ} \mathrm{C}$ for $24 \mathrm{~h}$ was a favorable condition to preserve all the blood samples before use. The supernatant was discarded after being centrifuged at $2700 \mathrm{rpm}$ for $5 \mathrm{~min}$. The cell suspension was washed with autoclaved isotonic saline solution. Centrifugation was repeated at the same parameters until the supernatant was clear and colorless. The pellet was resuspended in a $20 \%$ suspension $(v / v)$ with phosphate buffer saline $(10 \mathrm{mM}, \mathrm{pH} 7.4)$.

\subsubsection{Hypnotic Solution-Induced Haemolysis}

At first, a mixture of $0.5 \mathrm{~mL}$ of $20 \% \mathrm{RBC}$ suspension, $1 \mathrm{~mL}$ of phosphate buffer ( $\mathrm{pH} 7.4$, $0.15 \mathrm{M}$ ) and $2 \mathrm{~mL}$ of $0.25 \% \mathrm{NaCl}$ was prepared. Then, $0.5 \mathrm{~mL}$ of crude extracts at the concentration of $1000 \mu \mathrm{g} / \mathrm{mL}, 500 \mu \mathrm{g} / \mathrm{mL}$ and $250 \mu \mathrm{g} / \mathrm{mL}$ was added to the mixture and taken a break for $15 \mathrm{~min}$ at room temperature. At the same time, aspirin was taken as standard at the same concentration of that of extracts and a blank sample was prepared without any active compound as a control. The reaction mixture of aspirin and blank solution was made following the method mentioned previously. These samples were centrifuged at $5000 \mathrm{rpm}$ for $4-5 \mathrm{~min}$ and absorbance was taken at $530 \mathrm{~nm}$ by spectrophotometer [23]. The extent of inhibiting hemolysis was estimated according to the equation:

$\%$ of Stabilization activity $=100-\{($ absorbance of test sample $) /$ (absorbance of control) $\times 100\}$

\subsubsection{Bovine Albumin Denaturation Assay}

Aqueous solution ( $2 \mathrm{~mL}$ of $1 \%$ ) of calf albumin, $2.8 \mathrm{~mL}$ of phosphate-buffered saline (PBS, $\mathrm{pH}$ 6.4) and $2 \mathrm{~mL}$ of different concentrations of various extracts (CDCME, CEAE and $\mathrm{CMeE}$ ) so that final concentrations become 2000, 1000, and $500 \mu \mathrm{g} / \mathrm{mL}$ results in the preparation of $5 \mathrm{~mL}$ of the reaction mixture. Similar preparation without any active ingredient was taken as control. Then, the mixtures were warmed up at $\left(37.5^{\circ} \mathrm{C}\right)$ for 10-15 $\mathrm{min}$ and then an increase in temperature at $65^{\circ} \mathrm{C}$ was maintained for $5 \mathrm{~min}$. The absorbance of the cooled sample was measured at $650 \mathrm{~nm}$ by using the vehicle as blank. Aspirin at the final concentration of $(2000,1000,500 \mu \mathrm{g} / \mathrm{mL})$ was treated similarly as a reference drug for measurement of absorbance [24]. The extent of inhibition of protein denaturation was calculated by using the following formula:

$\%$ inhibition of denaturation $=($ absorbance of control-absorbance of sample)/(absorbance of control) $\times 100$

\subsection{In Vivo Anti-Inflammatory Activity \\ Carrageenan Induced Paw Edema Test}

Five groups comprised of five mice were formed for control, standard and 3 test sample groups. Group I: receiving 0.9\% saline, Group II: receiving Aspirin, Group III: treated with CDCME, Group IV: receiving CEAE and Group V: treated with CMeE. Every mouse was properly weighed so that it could receive $300 \mathrm{mg} / \mathrm{kg}$ doses of the examined samples and aspirin as standard adjusted to their body weight. After $30 \mathrm{~min}, 0.1 \mathrm{~mL}, 1 \% w / v$ carrageenan suspension in normal saline was injected into the subplantar tissue of the right hind paw. The volume of paw oedema was measured at $1 \mathrm{~h}$ increments for $4 \mathrm{~h}$ using water plethysmometer after administration of carageenan. The left paw was untreated to keep it usual to be compared [25]. The overall percentage of rise in paw volume with time was calculated using the formula below

$$
\% \text { of inhibition of paw edema }=(\mathrm{Vc}-(\mathrm{Vt} \times \mathrm{Vc})) \times 100
$$


where $\mathrm{V}_{\mathrm{c}}$ represents average paw volume of control group mice and $\mathrm{Vt}$ represents that of the treated animal, respectively.

\section{Statistical Analysis}

All data were presented as mean \pm SD taken with repetition for three times, and $5 \%, 1 \%$ and $0.1 \%$ level of significance (where ${ }^{*} p<0.05,{ }^{* *} p<0.01$ and ${ }^{* * *} p$ value $<0.001$, respectively) was performed between the control and treatment by one-way ANOVA followed by Dunnett T3 post hoc test using SPSS 22 software (IBM, Armonk, NY, USA).

\section{Results}

\subsection{Total Phenolic and Flavonoid Content}

The total amount of phenolic and flavonoid content in the three extracts of the plant Oldenlandia corymbosa $\mathrm{L}$. are represented in Table 1. The phenolic content was measured by the Folin-Ciocaltaeu assay and expressed in $\mathrm{mg} / \mathrm{g}$ of extract as that of gallic acid equivalent. The highest amount of phenolic compound was $190.25 \pm 48.68 \mathrm{mg} \mathrm{GAE} / \mathrm{g}$ of extract found in the CDCME and the lowest content of phenolic constituents was presented in CEAE (19.17 $\pm 5.20 \mathrm{mg} \mathrm{CAE} / \mathrm{g}$ od extract). The content of flavonoid is measured by colorimetric method and represented as catechin equivalent (CAE) in per gram dry extract weight. In our study, CDCME was revealed to contain highest amount of flavonoid content ( $235.33 \pm 42.95 \mathrm{mg}$ CAE$/ \mathrm{g}$ of extract) and the lowest amount was $87.67 \pm 61.49 \mathrm{mg}$ CAE $/ \mathrm{g}$ of extract that was present in $\mathrm{CMeE}$.

Table 1. Total phenolic, flavonoid content and extraction yield (\%) of the different extracts of Oldenlandia corymbosa L.

\begin{tabular}{cccc}
\hline $\begin{array}{c}\text { Plant } \\
\text { Extracts }\end{array}$ & $\begin{array}{c}\text { Extraction } \\
\text { Yield \% }\end{array}$ & $\begin{array}{c}\text { Total Phenolic (mg Gallic } \\
\text { Acid Equivalent/g) }\end{array}$ & $\begin{array}{c}\text { Total Flavonoid Content } \text { mg g }^{-\mathbf{1}} \\
\text { Plant Extract (in Catechine) }\end{array}$ \\
\hline CDCME & 12.61 & $190.25 \pm 48.68$ & $235.33 \pm 42.95$ \\
CEAE & 17 & $19 \pm 5.20$ & $88.83 \pm 52.01$ \\
CMeE & 22 & $92 \pm 60.39$ & $87.67 \pm 61.49$ \\
\hline
\end{tabular}

Each value in the table is represented as mean \pm SD $(n=3)$. LSD: Least significant difference; level of significance $* p<0.05$.

\subsection{DPPH Radical Scavenging Study}

The antioxidant characteristic of the plant extracts by DPPH radical scavenging was demonstrated in Table 2. The CDCME showed the significant antioxidant activity with $\mathrm{IC}_{50}$ value $473.86 \mu \mathrm{g} / \mathrm{mL}$ followed by the $\mathrm{CMeE}$ and CEAE with $507.2 \mu \mathrm{g} / \mathrm{mL}$ and $601.61 \mu \mathrm{g} / \mathrm{mL}$, respectively.

Table 2. Antioxidant activity of the extracts of Oldenlandia corymbosa L. by DPPH scavenging assay.

\begin{tabular}{cccc}
\hline Sample & Concentration & \% of DPPH Scavanging & IC $_{\mathbf{5 0}}$ Value \\
\hline \multirow{3}{*}{ Catechin } & 800 & $80.33 \pm 6.8$ & \\
& 400 & $59.67 \pm 9.53$ & $257.42 \pm 48.5$ \\
\multirow{2}{*}{ CDCME } & 200 & $48.33 \pm 10.82$ & \\
& 800 & $65.67 \pm 5.671$ & $473.86 \pm 13.6^{*}$ \\
CEAE & 400 & $52.97 \pm 2.12$ & \\
& 200 & $50.88 \pm 2.406$ & $601.61 \pm 184.07$ \\
& 800 & $54.33 \pm 13.017$ & \\
CMeE & 400 & $50.33 \pm 10.017$ & $570 \pm 9.56^{*}$ \\
& 200 & $42.67 \pm 39.526$ & \\
\hline
\end{tabular}

Data are expressed as mean $\pm \mathrm{SD}\left(n=3,{ }^{*} p<0.05\right)$. 


\subsection{Total Antioxidant Activity and Reducing Activity Test}

In the study of total antioxidant activity, the CDCME showed (Table 3) the maximum amount of antioxidant property $(0.63 \pm 0.039 *$ at the concentration of $800 \mu \mathrm{g} / \mathrm{mL})$. The result was found to be statistically significant $(p<0.05)$.

For the measurement of the reducing activity, we investigated the $\mathrm{Fe}^{3+}$ to $\mathrm{Fe}^{2+}$ transformation in the presence of the extracts and compared with the standard (catechin). The result of the reducing activity test is shown in Table 3. Like the antioxidant activity, the reducing activity of CDCME was found to be the highest $\left(0.41 \pm 0.046^{*}\right.$ at the concentration of $800 \mu \mathrm{g} / \mathrm{mL})$ and statistically significant $(p<0.05)$.

Table 3. Total antioxidant activity and reducing activity of the extracts of Oldenlandia corymbosa L.

\begin{tabular}{cccc}
\hline Sample & Concentration & Total Antioxidant Activity & Reducing Activity \\
\hline \multirow{3}{*}{ Catechin } & 800 & $0.791 \pm 0.041$ & $1.75 \pm 0.058$ \\
& 400 & $0.565 \pm 0.077$ & $1.63 \pm 0.114$ \\
CDCME & 200 & $0.32 \pm 0.15$ & $1.55 \pm 0.112$ \\
& 800 & $0.637 \pm 0.039 *$ & $0.41 \pm 0.046^{*}$ \\
CEAE & 400 & $0.237 \pm 0.032^{*}$ & $0.27 \pm 0.073^{*}$ \\
& 200 & $0.19 \pm 0.09^{*}$ & $0.23 \pm 0.123^{*}$ \\
CMeE & 400 & $0.441 \pm 0.058^{*}$ & $0.55 \pm 0.031^{*}$ \\
& 200 & $0.56 \pm 0.091$ & $0.25 \pm 0.024^{*}$ \\
& 800 & $0.18 \pm 0.11$ & $0.18 \pm 0.023$ \\
& 400 & $0.532 \pm 0.0366^{*}$ & $0.19 \pm 0.051^{*}$ \\
\hline
\end{tabular}

Values are presented as mean $\pm \operatorname{SD}\left(n=3,{ }^{*} p<0.05\right)$.

\subsection{In Vitro Anti-Inflammatory Activity Study}

Figure 1 demonstrated the result of anti-inflammatory study by both hypotonicity induced hemolysis and protein denaturation activity. As a RBC membrane can be ruptured by inflammation, the extent of anti-inflammation of the extracts was revealed by the protection of the RBC membrane compared to aspirin as a positive control. The CDCME showed the highest anti-inflammation, $97.24 \%$, at the concentration of $1000 \mu \mathrm{g} / \mathrm{mL}$. The $\mathrm{CMeE}$ also expressed remarkable activity $(72.42 \%)$ at the same concentration.

In the protein denaturation activity study, CDCME showed $52 \%$ of suppression of protein denaturation at the concentration of $1000 \mu \mathrm{g} / \mathrm{mL}$. The CMeE also revealed significant prevention of protein denaturation at about $68 \%$ concentration of $1000 \mu \mathrm{g} / \mathrm{mL}$.
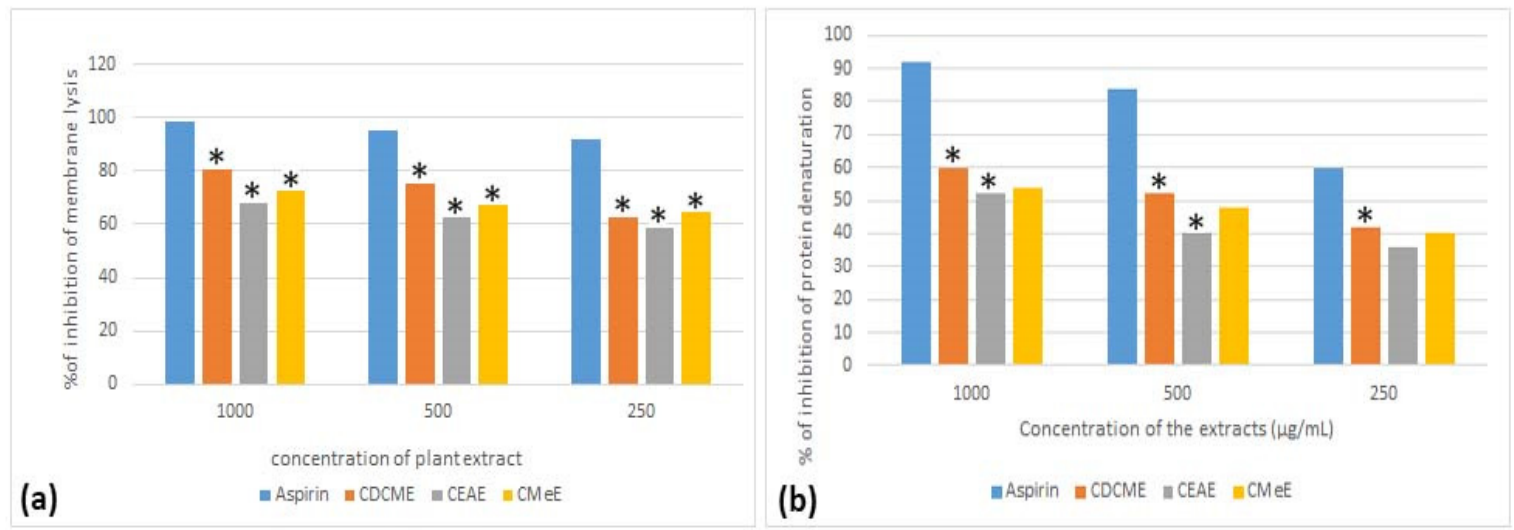

Figure 1. In vitro anti-inflammatory activity study of different extracts of Oldenalndia corymbosa. L at the concentration of 250, 500 and $1000 \mu \mathrm{g} / \mathrm{mL}$. (a) Percentage of hypotonicity induced membrane stabilization. (b) Percentage of protein denaturation. Data are presented as mean $\pm \operatorname{SD}(n=5),{ }^{*} p<0.05$ significant level is analyzed by One way ANOVA followed by Dunnett T3 post hoc test for values between the sample and control groups. 


\subsection{In Vivo Carrageenan Induced Paw Edema Test}

Table 3 showed the result of preventive effect of the extracts of Oldenlandia corymbosa L. against edema into Swiss albino mice. All the extracts showed moderate to high antiinflammatory activity with significance $(p<0.05)$. CDCME showed the highest percentage of reduction of paw edema that is $63.28 \%$ (after $3 \mathrm{~h}$ ) and 61.62\% (after $4 \mathrm{~h}$ ) when compared to control mice (Table 4).

Table 4. Effect of Oldenlandia corymbosa L. extracts on the carrageenan induced mice.

\begin{tabular}{|c|c|c|c|c|c|}
\hline \multirow{2}{*}{ Group } & \multirow{2}{*}{$\begin{array}{c}\text { Dose } \\
\mathrm{mg} / \mathrm{kg}\end{array}$} & \multicolumn{4}{|c|}{ Paw Edema Diameter in mm (\% of Inhibition) } \\
\hline & & 1st $\mathrm{h}$ & 2nd h & 3rd h & 4th $\mathrm{h}$ \\
\hline Control & $1 \%$ carageenan & $1.8 \pm 0.089$ & $1.87 \pm 0.045$ & $1.77 \pm 0.045$ & $1.65 \pm 0.087$ \\
\hline Aspirin & 10 & $\begin{array}{l}1.58 \pm 0.043 \text { * } \\
\quad(12.22)\end{array}$ & $\begin{array}{l}0.87 \pm 0.045 * \\
\quad(53.47)\end{array}$ & $\begin{array}{c}0.052 \pm 0.084 * \\
(97.06)\end{array}$ & $\begin{array}{l}0.52 \pm 0.084 \\
\quad(68.48)\end{array}$ \\
\hline CDCME & 300 & $1.87 \pm 0045$ & $\begin{array}{c}1.56 \pm 0.089 * \\
(16.58)\end{array}$ & $\begin{array}{c}0.65 \pm 0.087 * \\
(63.28)\end{array}$ & $\begin{array}{c}0.6425 \pm 0.03747 \\
(61.06) *\end{array}$ \\
\hline CEAE & 300 & $2.34 \pm 0.089$ & $\begin{array}{c}1.71 \pm 0.055 \text { * } \\
(8.56)\end{array}$ & $\begin{array}{c}1.1 \pm 0.485 \text { * } \\
(37.85)\end{array}$ & $\begin{array}{l}1.29 \pm 0.068 \\
(21.81)\end{array}$ \\
\hline CMeE & 300 & $\begin{array}{c}1.77 \pm 0.045 \text { * } \\
(1.67)\end{array}$ & $\begin{array}{c}1.28 \pm 0.027 * \\
(31.55)\end{array}$ & $\begin{array}{c}1.4 \pm 0.096 \\
(21)\end{array}$ & $\begin{array}{c}1.05 \pm 0.101 \\
\quad(36.36)\end{array}$ \\
\hline
\end{tabular}

post hoc test for values between the sample and control groups. Percentage of inhibition indicated as parenthesis.

\section{Discussion}

Although inflammation is natural response of immune and non-immune cells against infection caused by exogenous pathogens, shifting the response from short to long-lived results in a breakdown of immune tolerance leading to alteration in tissues and organs with increased risk of various non-communicable diseases [26]. In recent years, SARS-CoV-2 infection has been spread as pandemic all over the world, that involves overexpression of pro-inflammatory cytokines, e.g., IL-1, IL-6, IL-12, TNF- $\alpha$ and interferon gamma (IFN- $\gamma$ ), particularly in lung tissue resulting in multi-organ failure in severe cases [27]. Therefore, prevention of inflammation should be considered preferentially.

The first phase (1-2 h) of inflammation in carrageenan model, the mechanism is primarily facilitated by serotonin, histamine, and synthesis of prostaglandins in the injured tissue and in the latter phase prostaglandins release at a constant rate as well as polymorph nuclear cells secreted bradykinin, leukotrienes, and prostaglandins released from tissue macrophages mediate the phase [28]. The controlled release of mediators involved in the first phase of inflammation causes suppression of the early phase, whereas inhibition of the cyclooxygenase pathway results in restraint of the later phase. The conventional non-steroidal drugs exert their inhibitory effect of COX-2 enzyme that converts arachidonic acid to prostaglandin [29]. In this study, CDCME was more effective in the prevention of the mice paw oedema in comparison to other extracts. This could be due to the possibility that the extract contains some constituents that can inhibit inflammation by the suppressing the cyclooxygenase pathway.

During inflammation, the tertiary and secondary structure of protein is dissembled by the process of denaturation, resulting in the loss of its biological function [30]. Therefore, the ability of plant extract to inhibit protein denaturation was studied as one of the possible mechanisms of inflammation prevention. The CDCM extract showed considerable prevention of protein denaturation compared to the other extracts.

This oxidative stress resulting from impairment between free radicals and the body mechanism to scavenge them causes inflammatory transduction and pro-inflammatory substance release [31]. If lysosomal membrane is ruptured, phospholipase A2 (PLA2) catalyzes the hydrolysis of phospholipids resulting in formation of lysophospholipids and free fatty acid, e.g., arachidonic acid as a by-product. During the metabolic pathway of arachidonic acid, leukotrienes and prostaglandins are produced, whereas platelet activating factor (PAF) is derived via lysophospholipids pathway. Hypotonicity induced hemolysis is accompanied with unreasonable deposition of intracellular fluid that increases 
the permeability of RBC membrane. In this study, the CDCME showed significant extent of protection of RBC membrane. The release of serum protein and fluids into the RBC is inhibited by membrane equilibration in case of elevated absorbency induced by inflammatory mediators [32]. The prevention of rupture of the RBC membrane by CDCME implies that the extract can be responsible for inhibition of the formation of arachidonic acid. These also support the result of an in vivo carrageenan induced mice model experiment.

Noiarsa et al. reported that the plant extract possesses ten polar constituents including iridoid glucosides, lignin glucoside and flavonol glucoside [33]. It was observed that CDCME showed the most significant anti-inflammatory activity compared to the other two extracts in both in vivo and in vitro study. This suggests that the compounds that are responsible for anti-inflammatory property may most probably be semi-polar. Production of pro-inflammatory by arachidonic acid pathway, e.g., cyclooxygenase (COX), lipoxygenase (LOX), and phospholipase A2 (PLA2) can be prevented by flavonoids modulating nitric oxide synthetase [34]. In this study, we illustrated the presence of flavonoids and phenolic compounds. It can be expected that any or other compounds can exert the property of remedy from inhibition. Pain is a sign of inflammation, and in a previous study, we recommended the ethanolic extract of the plant Oldenlandia corymbosa L. as analgesic substrate [12]. Here, we have reported and evaluated for the first time the prevention of inflammation activity of the plant extract by considering a swelling parameter of inflammation.

During inflammation, activation of macrophage causes release of nitric oxide (NO) that is considered a strong free radical to initiate oxidation chain reaction. Free radicals contain unpaired electrons in their molecules that undergo chain reaction with cellular components and result in inflammation and many other pathological disorders [35]. The polyphenols exert antioxidant activity as the phenolic groups form a stable phenoxyl radical by accepting the unpaired electrons [36]. In the present study, it appears that CDCME is abundant with both phenolic and flavonoids that can exert free radical scavenging properties. The antioxidant property of the extract was studied by scavenging activity of DPPH, total antioxidant capacity and iron reducing activity. These experiments were connected to one another, demonstrating antioxidant activity. A previous study provided a correlation of the amount of polyphenolics with antioxidant activity of the methanolic extract of the plant [37]. In the present study, the extraction with solvent of gradual increasing polarity may have resulted in extraction of bioactive compounds in the semipolar solvent rather than the methanolic extract. As the CDCME turned out to be more effective as both an antioxidant and anti-inflammatory agent, semi-polar compounds may be liable to such properties.

\section{Conclusions}

The findings of this study support the view that medicinal plants are promising sources of potential antioxidants and anti-inflammatory agents that may be effective for therapy of human diseases. Studying the dichloromethane (CDCME) extract revealed a rich source of antioxidant and anti-inflammatory molecules. The results presented here, are encouraging for the use of this plant for medicinal purposes due to their antioxidant and anti-inflammatory properties. Further research is required for the isolation and identification of bioactive compounds within the plant extracts and to understand the mechanism of action and their use for disease management.

Author Contributions: Conceptualization: M.A.B., A.M. and R.Z.; Methodology: M.A.B. and M.A.I.; Software: M.A.B.; Validation: G.E.-S.B.; Formal analysis: M.A.B.; Investigation: A.M. and R.Z.; Resources: A.M.; Data curation: M.A.B.; Writing original draft preparation: M.A.B., R.Z.; Writing original draft and editing: R.Z., G.D.Z.; Visualization: A.A.; Supervision: R.Z.; Funding acquisition: M.A. All authors have read and agreed to the published version of the manuscript.

Funding: The research was funded by Taif University Project number (TURSP-2020/309), Taif University, Saudi Arabia. 
Institutional Review Board Statement: The study was conducted on mice model that followed guidelines of the Declaration of Helsinki and approved by the institutional ethical committee of Institute of Biological Sciences, University of Rajshahi, Bangladesh (license no: 225/320-IAMEBBC/IBSc).

Informed Consent Statement: Our study was not conducted by any human blood or tissue sample.

Data Availability Statement: The data that support the findings of this study are available from the corresponding author, [R.Z.], upon reasonable request.

Acknowledgments: The authors would like to extend their sincere appreciation to Taif University Researchers Supporting Project number (TURSP-2020/309), Taif University, Taif, Saudi Arabia. The authors would like to express their gratitude to BCSIR Laboratory that provided the research facilities. We are also grateful to Institute of Biological Science, University of Rajsahi for their kind support to conduct study on animal models.

Conflicts of Interest: The authors proclaim that they have no conflict of interest.

$\begin{array}{ll}\text { Abbreviations } \\ \text { DPPH } & \text { 1,1-Diphenyl-2-picrylhydrazyl radical } \\ \text { GAE } & \text { gallic acid equivalents } \\ \text { NSAID } & \text { Non-Steroidal Anti-Inflammatory Drugs } \\ \text { HRBC } & \text { Human Red Blood Corpuscles } \\ \text { RBC } & \text { Red Blood Cells } \\ \text { CDCME } & \text { Crude Dichloromethane Extract } \\ \text { CEAE } & \text { Crude Ethyle Acetate Extract } \\ \text { CMeE } & \text { Crude Methanol Extract } \\ \text { COC } & \text { Crude Oldenlandia corymbosa }\end{array}$

\section{References}

1. Ahmed, A. An overview of inflammation: Mechanism and consequences. Front. Biol. 2011, 6, 274. [CrossRef]

2. Jutila, M.A.; Rott, L.; Berg, E.L.; Butcher, E.C. Function and regulation of the neutrophil MEL-14 antigen in vivo: Comparison with LFA-1 and Mac-1. J. Immunol. 1989, 143, 3318-3324.

3. AR, O.; Joshua, P.; OV, E.; Nwodo, O. Anti-Inflammatory Effects of The Chloroform Extract of Annona muricata Leaves on Phospholipase A2 and Prostaglandin Synthase Activities. Transl. Biomed. 2017, 8, 137. [CrossRef]

4. Paramita, S.; Kosala, K.; Dzulkifli, D.; Saputri, I.; Wijayanti, E. Anti-inflammatory activities of ethnomedicinal plants from Dayak Abai in North Kalimantan, Indonesia. Biodiversitas 2017, 18, 1556-1561. [CrossRef]

5. Vazquez-Tello, A.; Halwani, R.; Hamid, Q.; Al-Muhsen, S. Glucocorticoid receptor-beta up-regulation and steroid resistance induction by IL-17 and IL-23 cytokine stimulation in peripheral mononuclear cells. J. Clin. Immunol. 2013, 33, 466-478. [CrossRef] [PubMed]

6. Abu-Serie, M.M.; Habashy, N.H.; Attia, W.E. In vitro evaluation of the synergistic antioxidant and anti-inflammatory activities of the combined extracts from Malaysian Ganoderma lucidum and Egyptian Chlorella vulgaris. BMC Complement. Altern. Med. 2018, 18, 154. [CrossRef]

7. Forrester, S.J.; Kikuchi, D.S.; Hernandes, M.S.; Xu, Q.; Griendling, K.K. Reactive Oxygen Species in Metabolic and Inflammatory Signaling. Circ. Res. 2018, 122, 877-902. [CrossRef] [PubMed]

8. Rodríguez-Yoldi, M.J. Anti-Inflammatory and Antioxidant Properties of Plant Extracts. Antioxidants 2021, 10, 921. [CrossRef] [PubMed]

9. Gupta, M.; Mazumder, U.K.; Gomathi, P.; Selvan, V.T. Antiinflammatory evaluation of leaves of Plumeria acuminata. BMC Complement. Altern. Med. 2006, 6, 1-6. [CrossRef]

10. Hussain, A.Z.; Kumaresan, S. Phytochemical and antimicrobial evaluation of Oldenlandia corymbosa. Asian J. Plant Sci. Res. 2013, 3, 155-158.

11. Mishra, K.; Dash, A.; Swain, B.; Dey, N. Antimalarial activities of Andrographis paniculata and Hedyotis corymbosa extracts and their combination with curcumin. Malar. J. 2009, 8, 26-29. [CrossRef] [PubMed]

12. Moniruzzaman, M.; Ferdous, A.; Irin, S. Evaluation of antinociceptive effect of ethanol extract of Hedyotis corymbosa Linn. whole plant in mice. J. Ethnopharmacol. 2015, 161, 82-85. [CrossRef]

13. Fatema, U.; Hossain, M. Analgesic effect of ethanol extract of Hedyotis corymbosa L. Whole plant. Int. Res. J. Pharm. 2014, 5, 21-24. [CrossRef]

14. Artanti, N.; Hanafi, M.; Andriyani, R.; Saraswaty, V.; Zalinar Udin, L.; D Lotulung, P.; Ichi Fujita, K.; Usuki, Y. Isolation of an Anti-Cancer Asperuloside from Hedyotis corymbosa L. J. Trop. Life Sci. 2015, 5, 88-91. [CrossRef]

15. Pandey, K.; Sharma, P.K.; Dudhe, R. Anticancer Activity of Parthenium hysterophorus Linn and Oldenlandia corymbosa Lam by Srb Method. Open Access Sci. Rep. 2012, 1, 1-3. [CrossRef] 
16. Mammen, D.; Daniel, M.; Sane, R.T. Identification of pharmacognostic and phytochemical biomarkers to distinguish between Hedyotis corymbosa (L.) Lam. and its adulterant, Glinus oppositifolius (L.) A. DC. Res. J. Pharm. Biol. Chem. Sci. 2011, 2, 649-656.

17. Sarma, A. Nutraceutical properties and antioxidant activity of Oldenlandia corymbosa L. found in brahmaputra valley agro- climatic conditions. World J. Pharm. Pharm. Sci. 2014, 3, 586-592.

18. Lee, Y.H.; Choo, C.; Watawana, M.I.; Jayawardena, N.; Waisundara, V.Y. An appraisal of eighteen commonly consumed edible plants as functional food based on their antioxidant and starch hydrolase inhibitory activities. J. Sci. Food Agric. 2015, 95, 2956-2964. [CrossRef]

19. Phuyal, N.; Jha, P.K.; Raturi, P.P.; Rajbhandary, S. Total Phenolic, Flavonoid Contents, and Antioxidant Activities of Fruit, Seed, and Bark Extracts of Zanthoxylum armatum DC. Sci. World J. 2020, 2020, 8780704. [CrossRef]

20. Braca, A.; Tommasi, N.; Di Bari, L.; Pizza, C.; Politi, M.; Morelli, I. Antioxidant principles from Bauhinia terapotensis. J. Nat. Prod. 2001, 64, 892-895. [CrossRef]

21. Prieto, P.; Pineda, M.; Aguilar, M. Spectrophotometric quantitation of antioxidant capacity through the formation of a phosphomolybdenum complex: Specific application to the determination of vitamin E. Anal. Biochem. 1999, 269, 337-341. [CrossRef] [PubMed]

22. Wang, J.; Hu, S.; Nie, S.; Yu, Q.; Xie, M. Reviews on Mechanisms of In Vitro Antioxidant Activity of Polysaccharides. Oxid. Med. Cell. Longev. 2016, 2016, 5692852. [CrossRef]

23. Azeem, A.K.; Dilip, C.; Prasanth, S.S.; Shahima, V.J.H.; Sajeev, K.; Naseera, C. Anti-inflammatory activity of the glandular extracts of Thunnus alalunga. Asian Pac. J. Trop. Med. 2010, 3, 794-796. [CrossRef]

24. Gambhire, M.; Juvekar, A.; Wankhede, S. Evaluation of anti-inflammatory activity of methanol extract of Barleria cristata leaves by in vivo and in vitro methods. Internet J. Pharmacol. 2009, 7, 1-6.

25. Yogesh, H.S.; Kichadi, S.C.; Muchandi, I.S.; Gopalakrishna, B. Evaluation of anti-inflammatory activity of Cynodon dactylon Pers. on carrageenan induced paw edema in rats. Indian J. Nat. Prod. Resour. 2013, 4, 151-154.

26. Taniguchi, K.; Karin, M. NF-кB, inflammation, immunity and cancer: Coming of age. Nat. Rev. Immunol. 2018, 18, 309-324. [CrossRef] [PubMed]

27. Costela-Ruiz, V.J.; Illescas-Montes, R.; Puerta-Puerta, J.M.; Ruiz, C.; Melguizo-Rodríguez, L. SARS-CoV-2 infection: The role of cytokines in COVID-19 disease. Cytokine Growth Factor Rev. 2020, 54, 62-75. [CrossRef]

28. Dash, S.; Kanungo, S.K.; Dinda, S. Anti-inflammatory activity of Aponogeton natans (Linn.) Engl. \& Krause in different experimental animal models. Der Pharm. Lett. 2013, 5, 136-140.

29. Shukla, S.; Mehta, A. In vivo anti-inflammatory, analgesic and antipyretic activities of a medicinal plant, Caesalpinia bonducella F. Pak. J. Pharm. Sci. 2015, 28, 1517-1521. [PubMed]

30. Anoop, M.V.; Bindu, A.R. In-vitro Anti-inflammatory Activity Studies on Syzygium zeylanicum (L.) DC Leaves. Int. J. Pharma Res. Rev. 2015, 4, 18.

31. Seril, D.N.; Liao, J.; Yang, G.-Y.; Yang, C.S. Oxidative stress and ulcerative colitis-associated carcinogenesis: Studies in humans and animal models. Carcinogenesis 2003, 24, 353-362. [CrossRef]

32. Anosike, C.A.; Obidoa, O.; Ezeanyika, L.U. Membrane stabilization as a mechanism of the anti-inflammatory activity of methanol extract of garden egg (Solanum aethiopicum). Daru 2012, 20, 76. [CrossRef]

33. Noiarsa, P.; Ruchirawat, S.; Otsuka, H.; Kanchanapoom, T. Chemical constituents from Oldenlandia corymbosa L. of Thai origin. J. Nat. Med. 2008, 62, 249-250. [CrossRef]

34. Bassiouni, W.; Daabees, T.; Louedec, L.; Norel, X.; Senbel, A. Evaluation of some prostaglandins modulators on rat corpus cavernosum in-vitro: Is relaxation negatively affected by COX-inhibitors? Biomed. Pharmacother. 2019, 111, 1458-1466. [CrossRef]

35. Bhandare, A.; Kshirsagar, A.; Vyawahare, N.; Hadambar, A.; Thorve, V. Potential analgesic, anti-inflammatory and antioxidant activities of hydroalcoholic extract of Areca catechu L. nut. Food Chem. Toxicol. 2010, 48, 3412-3417. [CrossRef]

36. Altowyan, M.S.; Barakat, A.; Al-Majid, A.M.; Al-Ghulikah, H.A. Spiroindolone analogues bearing benzofuran moiety as a selective cyclooxygenase COX-1 with TNF- $\alpha$ and IL-6 inhibitors. Saudi J. Biol. Sci. 2020, 27, 1208-1216. [CrossRef]

37. Sasikumar, J.; Maheshu, V.; Aseervatham, S.; Darsini, D. In vitro antioxidant activity of Hedyotis corymbosa (L.) Lam. aerial parts. Indian J. Biochem. Biophys. 2010, 47, 49-52. [PubMed] 